\title{
Laboratory results of foam application testing for longwall shield dust control in a simulated environment
}

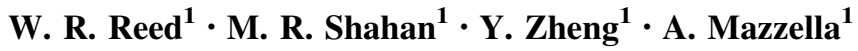

Received: 18 June 2020/Revised: 25 January 2021 / Accepted: 3 February 2021/Published online: 2 March 2021

(C) The Author(s) 2021

\begin{abstract}
There were 37 longwall faces operating in mines in the United States in 2019. The average panel width for these longwalls was approximately $368.5 \mathrm{~m}$ (1209 ft). This translates to a range of approximately 170-240 shields per longwall, depending upon the width of shield. The movement of longwall shields is a significant contributor to respirable dust overexposures to longwall operators. Foam is expected to have the potential to reduce this shield dust generation. The foam is applied to the area on the roof between the coal face and the shield tip after the shearer passes. In this study, the longwall shield dust simulator was used to test three foam agents for their ability to control dust from longwall shield movements. Results showed that at low-velocity ventilation $(\approx 3.0 \mathrm{~m} / \mathrm{s}(600 \mathrm{fpm}))$ all foam agents were able to produce dust reduction levels of at least $45 \%$. At high-velocity ventilation $(\approx 5.1 \mathrm{~m} / \mathrm{s}(1000 \mathrm{fpm}))$, the reductions were lower and more variable, ranging from being undeterminable for one foam agent to having 46\%-63\% reductions for the other two foam agents, with one instance of an increase in dust concentration. Overall, the use of foam agents can provide longwall shield dust control. Important factors are roof coverage and the ability of foam to remain on the roof for extended time periods.
\end{abstract}

Keywords Longwall $\cdot$ Shields $\cdot$ Foam $\cdot$ Respirable Dust $\cdot$ Silica Dust

\section{Introduction}

Through the end of the year 2019, there were 37 longwall faces operating in underground coal mines in the United States. These longwalls produced an approximate total of 147.9 million metric tons (163 million U.S. tons) of coal. The average panel width was $1209 \mathrm{ft}$ with a panel length of $12,204 \mathrm{ft}$ and an average height of 96.7 inches (Fiscor 2020). A $368.5 \mathrm{~m}$ (1209 ft) average panel width can correspond to an average of approximately 170-240 shields,

Disclaimer The findings and conclusions in this paper are those of the authors and do not necessarily represent the official position of the National Institute for Occupational Safety and Health, Centers for Disease Control and Prevention. Mention of company names or products does not constitute endorsement by NIOSH.

\footnotetext{
W. R. Reed

rreed@cdc.gov

1 CDC-NIOSH, Pittsburgh, PA, USA
}

depending upon the width of the shields being used (Komatsu Joy Global 2020). Figure 1 shows a section of a typical longwall shearer with shields. The arrows show the ventilation airflow, with the filled arrows showing the dusty air generated by the shearer that is pushed to the face by the shearer clearer system. The panel length is perpendicular from the panel width.

With this many shields, advancing longwall shields can expose the downwind operators to significant amounts of respirable dust. Foam applications have been thought to be an effective means of conglomerating respirable dust particles, causing them to settle out of the air. Coating the mine roof with foam as the shearer passes may allow for the pretreatment of the mine roof, reducing the amount of respirable dust produced by shield movements. The shields will advance into a foam coated area, pressing up into the mine roof, with the goal of reducing the respirable dust generation.

A laboratory model that could simulate the mechanism and interaction of dust generation induced by shield 




Fig. 1 A typical section of a longwall shearer with shields showing ventilation airflows. The panel length is perpendicular to the panel width

advancement was developed by the researchers from the National Institute for Occupational Safety and Health (NIOSH). The test apparatus would be able to compress a known mass of dust and advance the material along a simulated mine roof, emulating the motion that occurs during a shield advance (Shahan and Reed 2019). The goal of the study is to determine the amount of dust that is able to be suppressed by the foam application to determine its potential in real-world applicability.

Previous experiments by NIOSH researchers have successfully applied foam onto a simulated mine roof for two foam agents, $\mathrm{A}$ and $\mathrm{B}$, which are evaluated for dust control potential in this paper. These compressed air foam coverages are all above or close to $90 \%$ after $3 \mathrm{~min}$, in other words, $90 \%$ of the roof was covered with the foam-sticking to the roof without ventilation or at a $3.3 \mathrm{~m} / \mathrm{s}(650 \mathrm{fpm})$ airflow ventilation rate. The 3 -min time frame is significant as this represents the approximate time between the shearer passing a shield and the shield movement, which is based upon observations of longwall shield movement. The compressed-air-generated foam has demonstrated potential for effective shield dust control through its application to the mine roof (Reed et al. 2017).

However, compressed-air-generated foam was not evaluated in this study due to Mine Safety and Health Administration (MSHA) regulations on air compressors (Code of Federal Regulations, CFR 75.344 2018). The regulations apply to electrical compressors $>5 \mathrm{hp}$ which are not a component of existing equipment. The regulations require extra attention to the compressor by requiring constant monitoring of the compressor with the ability to de-energize the compressor. The regulations may also require fire suppression systems, incombustible enclosures, special ventilation requirements, heat sensors, and carbon monoxide sensors for use of the air compressor. Due to the extra precautions required by regulations, the use of aircompressor-generated foam was not deemed feasible for use in underground coal mining. Therefore, compressedair-generated foam was not evaluated in this study.

Blowers or fans do not require the extra precautions as that are required when using air compressors. Blowers provide high volume airflow at low pressure, while compressed air can provide high volume airflow at high pressure (Reed et al 2018). Therefore, blower-air-generated foam was evaluated for longwall shield dust control. Blower air foam results are different from compressed-airgenerated foam. Their roof coverage area is highly dependent upon nozzle selection. The high expansion ratios of these foams also reduces the amount of time that is available for dust control as high ventilation airflow tends to cause rapid decay of the foam. The blower-generated foams are generally stable for the 3-min time frame for shield movement (Reed et al. 2017).

\section{Test protocol}

The first step in the testing in this study was to conduct baseline dust generation testing and then test for foam agent dust control. Three foam agents were evaluated and are labeled $\mathrm{A}, \mathrm{B}$, and $\mathrm{C}$. The agents are different formulations-foam agent A is a Butyl diglycol, B is a Sodium alpha olefin sulfonate and $\mathrm{C}$ is a Benzene sulfonic acid, dodecyl-, sodium salt. All foam applications (agents, A, B, and $\mathrm{C}$ ) were compared with baseline tests without foam application. Table 1 presents some basic properties of the foam agents.

Baseline testing experiments were conducted first and were completed in the test facility without any dust controls. Then, foam dust control testing was conducted applying foam onto a simulated mine roof. Airflow ventilation velocities of $3.0 \mathrm{~m} / \mathrm{s}(600 \mathrm{fpm})$ and $5.1 \mathrm{~m} / \mathrm{s}(1000$ fpm) were evaluated. A 3-min time wait between foam application and shield movement was conducted as this represented the approximate time between the shearer 
Table 1 Foam agents and their associated properties

\begin{tabular}{llllllll}
\hline Foam agent & Color & Odor & $\mathrm{pH}$ & Flash point $\left({ }^{\circ} \mathrm{C}\right)$ & $\begin{array}{l}\text { Density }(\mathrm{g} / \\
\mathrm{cc})\end{array}$ & Primary chemical components & $\begin{array}{l}\text { Surfactant } \\
\text { type }\end{array}$ \\
\hline A & Light yellow & Slight & $7.0-9.0$ & N/A* & 1.015 & Butyl diglycol & Nonionic \\
B & Pale yellow & Bland & $7.0-9.0$ & N/A* & 1.06 & Sodium alpha olefin sulfonate & $\begin{array}{l}\text { Anionic } \\
\text { C }\end{array}$ \\
\hline
\end{tabular}

Note $N / A *$ refers to not available because agent is an aqueous solution, $N / D$ refers to not determined

passing a shield and the shield movement, which is based upon observations of longwall shield movement. Comparisons of the baseline testing and the foam dust control testing were completed.

\subsection{Test apparatus design}

A $1.2 \mathrm{~m} \times 0.2 \mathrm{~m} \times 9.1 \mathrm{~m}(48$ in $\times 8$ in $\times 30 \mathrm{ft})$ wind tunnel was constructed. The dimensions of the tunnel were selected to provide the desired ventilation airflow at the dust sampling locations. The tunnel is connected to the Arrestall Model AR55 baghouse. This baghouse has the capacity to move $1.2-2.8 \mathrm{~m}^{3} / \mathrm{s}(2500-6000 \mathrm{cfm})$ airflow, dependent upon fan static pressures, with the lower static pressures allowing higher airflow. Figure 2 shows the wind tunnel experimental facility that was used for this project.


the wind tunnel was constructed that could simulate the mechanics involved with a shield movement. The top surface of the test chamber representing the mine roof was designed as a removable Sect. $0.6 \mathrm{~m} \times 1.2 \mathrm{~m}(24 \mathrm{in} \times 48$ in) so that the surface could be removed and replaced with a clean surface between simulations. The 0.6-m (24-in) width was selected as it represents the coverage that the foam spray nozzle can achieve. The bottom plate represented the longwall shield roof and was designed to be removed for easy loading of dust material. Air actuators allowed for up and down movement and cross-tunnel travel of the bottom plate. Figure 3 shows a closeup picture of the test chamber. It shows the configuration of the bottom plate loaded with the gravel mixture and the top plate which is coated with foam. The bottom plate moves upward as it travels across the chamber. This facility is detailed in prior research (Shahan and Reed 2019).

The computer was used to control the movement of the bottom plate (which represents the longwall shield movement). The bottom plate traverse travel profile is shown in Table 2. During the traverse, analog-to-USB signal converters were used to transmit sampling data back to the computer.

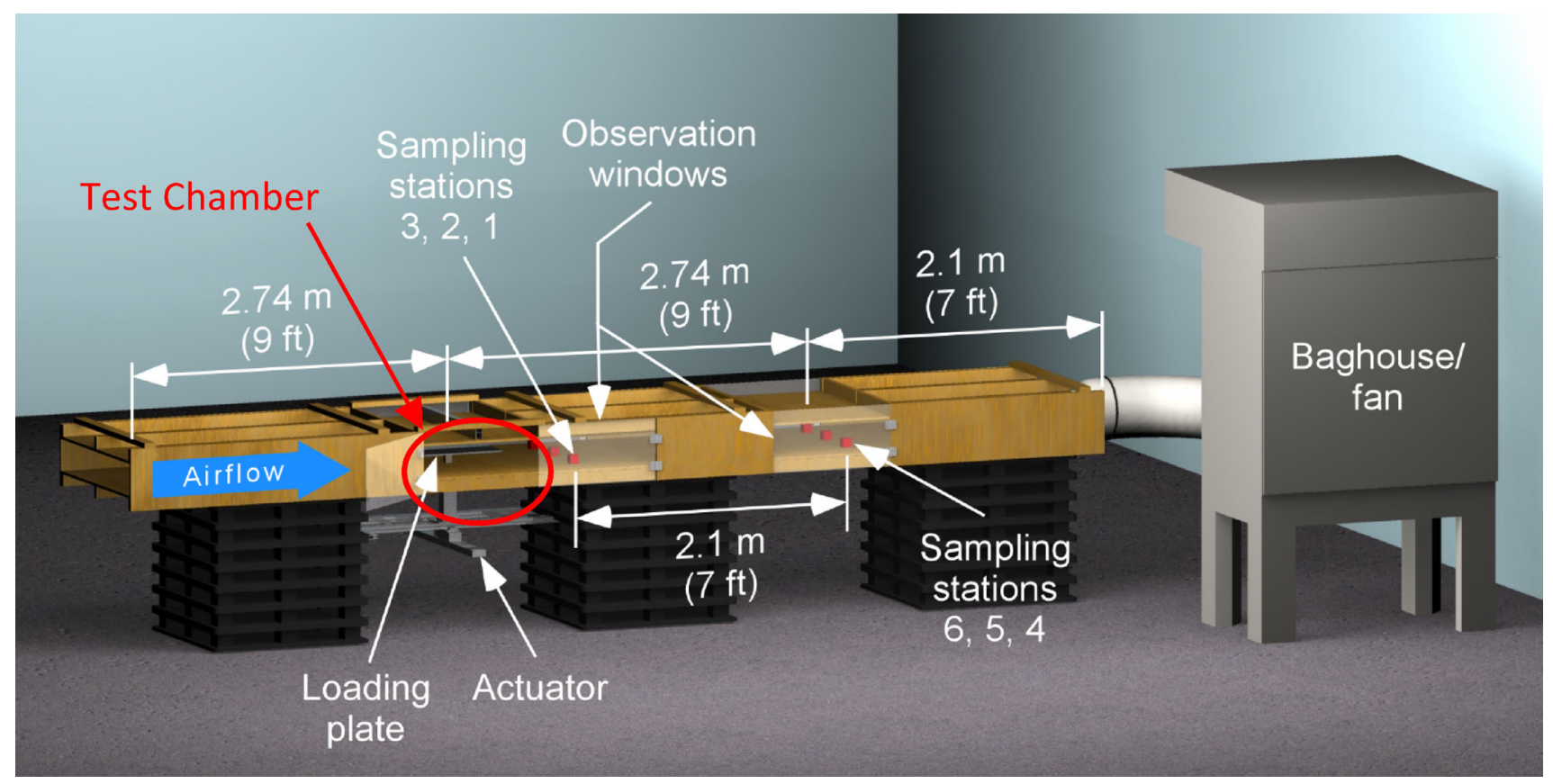

Fig. 2 Diagram of the wind tunnel experimental facility for testing longwall shield dust control 




Fig. 3 Inside view of the test chamber (shown in Fig. 1) as the bottom plate completes a traverse. It is at location Plate drops/lowers halfway as stated in Table 2

\subsection{Sampling methods}

Two air sampling locations were situated downstream of the test chamber. Air sampling location one is $0.6 \mathrm{~m}$ (24 in) from the test chamber and contains samplers 1, 2, and 3 .

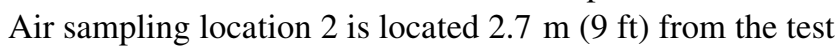
chamber and contains samplers 4,5 , and 6 . Each sampler consists of a personal DataRAM ${ }^{\mathrm{TM}}$ pDR-1000 (pDR). The pDR measures instantaneous dust concentrations as the actuator operates and moves across the wind tunnel and back. The pDR was connected to the Labview program and recorded dust concentrations at 0.5 -s intervals. The pDR units were equally spaced across the wind tunnel to capture the dust gradient generated during the shield movement simulation (Fig. 4). The pDRs used at each location were the same pDRs used through the testing. There was no substitution of pDRs, except toward the end of testing when the foam application disabled a pDR by contaminating the light-scattering sensing chamber. This contamination only occurred on the first row of samplers (locations 1, 2, and 3).

The dust concentration results presented are only based upon the pDR samplers. Originally, gravimetric samplers, consisting of a $10-\mathrm{mm}$ Dorr-Oliver cyclone with a $37-\mathrm{mm}$ diameter filter cassette operating at a flow rate of $2.0 \mathrm{lpm}$, were considered to be used alongside the pDRs to aid in the determination of the airborne mass concentration of respirable coal dust emitted from the shield movement simulation. This gravimetric measurement acquired during testing would be used to calibrate the pDR data collected during testing (Williams and Timko 1984; Reed et al. 2012). The gravimetric samplers were not used because during early testing it was found that the amount of material that dropped from the dust plate was a sufficiently large mass that deluged the sampler inlets and overloaded the gravimetric samplers. This large mass of material dumped directly into the cyclone inlet, overwhelming the gravimetric sampler, and it did not impact the pDR because of its shielded inlet and due to the pDR being a passive sampler. The gravimetric samplers are active and actively pull airflow into the sampling (cyclone) inlet, which aided the large amount of dust entering the sampler. Additionally, during foam testing, it was observed that the foam also entered the cyclone inlet, thereby, contaminating the sample on the $37-\mathrm{mm}$ filters.

Shielding the gravimetric inlet was considered but rejected. Past research has suggested that shielding of the cyclone inlets could aid in protecting samplers from overloading due to the projection of coarse particles to the sampler inlet (Görner et al. 2010; Belle et al. 2000). Shielding was not employed due to the additional testing that would be required to determine the effectiveness of shielding on sampling. Additionally, with the amount of material being projected onto the first row of samplers, shielding the gravimetric samplers would not have provided sufficient protection to prevent overwhelming from the projected material. Therefore, gravimetric sampling was not used in this analysis. Only the data from the pDRs were used in the analysis. So, all dust concentration measurements are from pDRs and are relative concentrations not absolute concentrations.

In some instances, the foam also inundated the pDR samplers. However, the foam was not observed to enter the pDR measurement chamber. The problem of inundation of the pDRs was solved by removing the excess foam by vacuuming from the test facility in between the tests.

The use of the pDR without gravimetric sampling produces relative concentrations. These concentrations can be affected by particle shape, density, size, and surface properties or index of refraction (Williams and Timko 


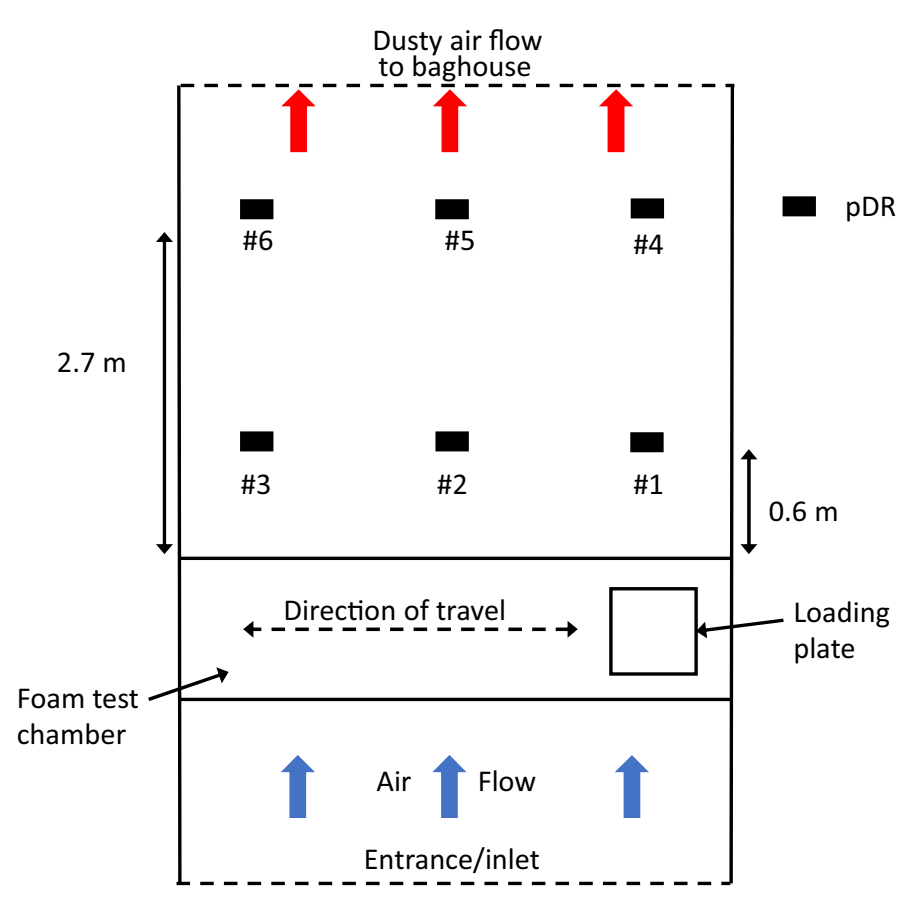

Fig. 4 A schematic showing the plan view layout of the pDRs in the foam test facility (not to scale)

1984). Which is why calibration with a gravimetric sampler is recommended in order to obtain absolute concentrations. Relative concentrations are acceptable for analysis, but there are limitations. The relative concentration data from an individual pDR can be evaluated. However, because of internal electronic characteristics, the relative concentration data cannot be compared across different pDR instruments. Therefore, since the same pDRs were used at each location, the data from each location is only comparable to itself.

\subsection{Test material}

A gravel mixture was created that was representative of the material that is usually found on top of the longwall shield and is the source of the shield-generated dust. The gravel mixture was formulated as a mixture of bagged Quikrete gravel \#1151 and bagged Quikrete sand \#1152. The bagged gravel and sand were sieved to collect the two size fractions $9.5-4.75 \mathrm{~mm}$ and $4.76-1.18 \mathrm{~mm}$. Sieving was completed using a shaker screen (Gilson Testing Screen, Gilson Company, Inc., Model No. TS2) containing $58.4 \mathrm{~cm} \times$ $36.8 \mathrm{~cm}$ screens. The mixture was created by blending equal parts of these two size fractions. This gravel mixture was used successfully in previous shield dust testing that

Table 2 Bottom plate traverse travel profile with programmed times to simulate longwall shield movement

\begin{tabular}{lll}
\hline Plate location & Baseline time (s) & Foam time (s) \\
\hline Shield movement simulation traverse & & $180.00 *+0$ \\
Start movement across facility (plate moves up and across simultaneously) & 0 & $180.00+7.00$ \\
Plate hits roof & 7.00 & $180.00+12.25=192.25$ \\
Plate finishes traverse across facility & 12.25 & \\
Return/reset traverse & & $180.00+13.30=193.30$ \\
Plate drops/lowers halfway & 13.30 & $180.00+19.00=199.00$ \\
Plate completes return traverse & 19.00 & $180.00+27.50=207.50$ \\
Plate finishes lowering/returns to start location & 27.50 & 207.50 \\
Total time for traverse and reset & 27.50 & \\
$* 180.00 \mathrm{~s}$ represents the 3-min wait time for shield movement & & \\
\hline
\end{tabular}


Table 3 Summary of dust percent changes at $3.0 \mathrm{~m} / \mathrm{s}(600 \mathrm{fpm})$ for mixed gravel using foam agent A. Based upon average value of traverse

\begin{tabular}{lllllllll}
\hline Location & $\begin{array}{l}\text { Baseline } \\
\left(\mathrm{mg} / \mathrm{m}^{3}\right)\end{array}$ & $\begin{array}{l}\text { Foam } \\
\left(\mathrm{mg} / \mathrm{m}^{3}\right)\end{array}$ & $\begin{array}{l}\text { Change } \\
(\%)\end{array}$ & $t$ test @ 95\% confidence & $\begin{array}{l}\text { Statistically } \\
\text { significant }\end{array}$ & $\begin{array}{l}\text { Foam } \\
\text { expansion }\end{array}$ & $\begin{array}{l}\text { Drainage } \\
\text { Concentration } \\
(\%)\end{array}$ \\
\hline 1 & 0.473 & 0.318 & 32.64 & $t(54)=4.44, p=4.53 \times 10^{-5}$ & Yes & 44.1 & 4 & 1.22 \\
2 & 2.642 & 0.557 & 78.92 & $t(45)=3.81, p=4.25 \times 10^{-4}$ & Yes & 44.1 & 4 & 1.22 \\
3 & 0.536 & 0.384 & 28.31 & $t(75)=1.23, p=0.222$ & No & 44.1 & 4 & 1.22 \\
4 & 0.911 & 0.170 & 81.37 & $t(42)=4.22, p=1.27 \times 10^{-4}$ & Yes & 44.1 & 4 & 1.22 \\
5 & 2.150 & 0.355 & 83.48 & $t(43)=4.07, p=1.97 \times 10^{-4}$ & Yes & 44.1 & 4 & 1.22 \\
6 & 1.281 & 0.367 & 71.37 & $t(42)=3.41, p=0.001$ & Yes & 44.1 & 4 & 1.22 \\
\hline
\end{tabular}

Table 4 Summary of dust percent changes at $5.1 \mathrm{~m} / \mathrm{s}(1000 \mathrm{fpm})$ for mixed gravel using foam agent A. Based upon average value of traverse

\begin{tabular}{|c|c|c|c|c|c|c|c|c|}
\hline Location & $\begin{array}{l}\text { Baseline } \\
\left(\mathrm{mg} / \mathrm{m}^{3}\right)\end{array}$ & $\begin{array}{l}\text { Foam }(\mathrm{mg} / \\
\left.\mathrm{m}^{3}\right)\end{array}$ & $\begin{array}{l}\text { Change } \\
(\%)\end{array}$ & $t$ test @95\% confidence & $\begin{array}{l}\text { Statistically } \\
\text { significant }\end{array}$ & $\begin{array}{l}\text { Foam } \\
\text { expansion }\end{array}$ & Drainage & $\begin{array}{l}\text { Concentration } \\
(\%)\end{array}$ \\
\hline 1 & 0.377 & 6.373 & -1590.64 & $\begin{array}{l}t(41)=11.00 \\
\quad p=8.20 \times 10^{-14}\end{array}$ & Yes & 47.5 & 0 & 1.70 \\
\hline 2 & 5.917 & 4.281 & 27.64 & $t(45)=1.51, p=0.138$ & Yes & 47.5 & 0 & 1.70 \\
\hline 3 & 0.803 & 0.884 & -10.15 & $t(51)=0.50, p=0.620$ & No & 47.5 & 0 & 1.70 \\
\hline 4 & 0.827 & 2.776 & -235.74 & $\begin{array}{l}t(46)=3.91 \\
\quad p=3.00 \times 10^{-4}\end{array}$ & Yes & 47.5 & 0 & 1.70 \\
\hline 5 & 5.213 & 2.786 & 46.56 & $t(59)=2.11, p=0.039$ & Yes & 47.5 & 0 & 1.70 \\
\hline 6 & 5.203 & 2.722 & 47.69 & $t(60)=2.07, p=0.043$ & Yes & 47.5 & 0 & 1.70 \\
\hline
\end{tabular}

Table 5 Summary of dust percent changes at $3.0 \mathrm{~m} / \mathrm{s}(600 \mathrm{fpm})$ for mixed gravel using foam agent B. Based upon average value of traverse

\begin{tabular}{|c|c|c|c|c|c|c|c|c|}
\hline Location & $\begin{array}{l}\text { Baseline (mg/ } \\
\left.\mathrm{m}^{3}\right)\end{array}$ & $\begin{array}{l}\text { Foam }(\mathrm{mg} / \\
\left.\mathrm{m}^{3}\right)\end{array}$ & $\begin{array}{l}\text { Change } \\
(\%)\end{array}$ & $t$ test @95\% confidence & $\begin{array}{l}\text { Statistically } \\
\text { significant }\end{array}$ & $\begin{array}{l}\text { Foam } \\
\text { expansion }\end{array}$ & Drainage & $\begin{array}{l}\text { Concentration } \\
(\%)\end{array}$ \\
\hline 1 & 0.118 & 0.167 & -41.45 & $\begin{array}{l}t(55)=10.64 \\
\quad p=5.69 \times 10^{-15}\end{array}$ & Yes & 53.5 & 26 & 0.73 \\
\hline 2 & 0.663 & 0.530 & 20.09 & $t(82)=0.41, p=0.681$ & No & 53.5 & 26 & 0.73 \\
\hline 3 & 0.891 & 0.650 & 27.04 & $t(76)=1.05, p=0.296$ & No & 53.5 & 26 & 0.73 \\
\hline 4 & 0.181 & 0.095 & 47.62 & $\begin{array}{l}t(46)=3.71 \\
\quad p=5.60 \times 10^{-4}\end{array}$ & Yes & 53.5 & 26 & 0.73 \\
\hline 5 & 1.160 & 0.389 & 66.47 & $t(49)=3.09, p=0.003$ & Yes & 53.5 & 26 & 0.73 \\
\hline 6 & 1.948 & 0.684 & 64.90 & $t(51)=2.83, p=0.007$ & Yes & 53.5 & 26 & 0.73 \\
\hline
\end{tabular}

characterized the shield airborne dust (Chekan et al. 2004). The only difference from the previous test material was the elimination of the mineral black from the gravel formulation. This gravel mixture was loaded onto the bottom plate using a 12.7-mm jig that provided support for the gravel at the edge of the plate. Once the material was loaded, the jig was removed, and the plate was ready to place in the test facility.

\subsection{Test trials}

Testing was completed using blower-air-generated foam, with the three different foaming agents. The concentrations of the foam agents were controlled using a critical orifice in the siphon valve used to add foam agent into the water line. The concentrations were targeted to be below $2 \%$. Tables 3, 4, 5, 6, 7 and 8 show the concentrations of the foam agent during testing. Two ventilation flow velocities were tested-3.0 m/s (600 fpm) and $5.1 \mathrm{~m} / \mathrm{s}(1000 \mathrm{fpm})$. The trials were based upon foam agent type and airflow. Each trial conducted a baseline test (no foam) and a foam 
Table 6 Summary of dust percent changes at $5.1 \mathrm{~m} / \mathrm{s}(1000 \mathrm{fpm})$ for mixed gravel using foam agent B. Based upon average value of traverse

\begin{tabular}{|c|c|c|c|c|c|c|c|c|}
\hline Location & $\begin{array}{l}\text { Baseline (mg/ } \\
\left.\mathrm{m}^{3}\right)\end{array}$ & $\begin{array}{l}\text { Foam }(\mathrm{mg} / \\
\left.\mathrm{m}^{3}\right)\end{array}$ & $\begin{array}{l}\text { Change } \\
(\%)\end{array}$ & $t$ test @95\% confidence & $\begin{array}{l}\text { Statistically } \\
\text { significant }\end{array}$ & $\begin{array}{l}\text { Foam } \\
\text { expansion }\end{array}$ & Drainage & $\begin{array}{l}\text { Concentration } \\
(\%)\end{array}$ \\
\hline 1 & 0.406 & 0.389 & 4.25 & $\begin{array}{c}t(67)=0.179 \\
p=0.859\end{array}$ & No & 56 & 20 & 1.50 \\
\hline 2 & 15.275 & 27.340 & -78.98 & $t(81)=2.30, p=0.024$ & Yes & 56 & 20 & 1.50 \\
\hline 3 & 1.619 & 6.594 & -307.19 & $\begin{array}{l}t(52)=5.26 \\
\quad p=2.72 \times 10^{-6}\end{array}$ & Yes & 56 & 20 & 1.50 \\
\hline 4 & 1.112 & 1.282 & -15.30 & $\begin{array}{c}t(77)=0.5653 \\
\quad p=0.575\end{array}$ & No & 56 & 20 & 1.50 \\
\hline 5 & 5.524 & 5.471 & 0.97 & $t(82)=0.32, p=0.974$ & No & 56 & 20 & 1.50 \\
\hline 6 & 5.197 & 4.047 & 22.14 & $\begin{array}{c}t(77)=0.800 \\
p=0.426\end{array}$ & No & 56 & 20 & 1.50 \\
\hline
\end{tabular}

Table 7 Summary of dust percent changes at $3.0 \mathrm{~m} / \mathrm{s}(600 \mathrm{fpm})$ for mixed gravel using foam agent C. Based upon average value of traverse

\begin{tabular}{|c|c|c|c|c|c|c|c|c|}
\hline Location & $\begin{array}{l}\text { Baseline (mg/ } \\
\left.\mathrm{m}^{3}\right)\end{array}$ & $\begin{array}{l}\text { Foam }(\mathrm{mg} / \\
\left.\mathrm{m}^{3}\right)\end{array}$ & $\begin{array}{l}\text { Change } \\
(\%)\end{array}$ & $t$ test @ 95\% confidence & $\begin{array}{l}\text { Statistically } \\
\text { significant }\end{array}$ & $\begin{array}{l}\text { Foam } \\
\text { expansion }\end{array}$ & Drainage & $\begin{array}{l}\text { Concentration } \\
(\%)\end{array}$ \\
\hline 1 & 0.549 & 2.424 & -341.22 & $\begin{array}{l}t(43)=3.79 \\
\quad p=4.63 \times 10^{-4}\end{array}$ & Yes & 49 & 36 & 1.05 \\
\hline 2 & 4.538 & 4.642 & -2.28 & $t(69)=1.45, p=0.15$ & No & 49 & 36 & 1.05 \\
\hline 3 & 3.047 & 1.702 & 44.14 & $t(75)=0.92, p=0.36$ & No & 49 & 36 & 1.05 \\
\hline 4 & 1.943 & 1.024 & 47.31 & $t(59)=2.01, p=0.049$ & Yes & 49 & 36 & 1.05 \\
\hline 5 & 5.295 & 1.936 & 63.43 & $t(50)=2.82, p=0.007$ & Yes & 49 & 36 & 1.05 \\
\hline 6 & 4.703 & 1.842 & 60.84 & $t(53)=2.72, p=0.009$ & Yes & 49 & 36 & 1.05 \\
\hline
\end{tabular}

Table 8 Summary of dust percent changes at $5.1 \mathrm{~m} / \mathrm{s}(1000 \mathrm{fpm})$ for mixed gravel using foam agent C. Based upon average value of traverse

\begin{tabular}{|c|c|c|c|c|c|c|c|c|}
\hline Location & $\begin{array}{l}\text { Baseline }(\mathrm{mg} / \\
\left.\mathrm{m}^{3}\right)\end{array}$ & $\begin{array}{l}\text { Foam }(\mathrm{mg} / \\
\left.\mathrm{m}^{3}\right)\end{array}$ & $\begin{array}{l}\text { Change } \\
(\%)\end{array}$ & $t$ test @ 95\% confidence & $\begin{array}{l}\text { Statistically } \\
\text { significant }\end{array}$ & $\begin{array}{l}\text { Foam } \\
\text { expansion }\end{array}$ & Drainage & $\begin{array}{l}\text { Concentration } \\
(\%)\end{array}$ \\
\hline 1 & 0.293 & 0.032 & 88.89 & $\begin{array}{l}t(42)=4.33 \\
\quad p=9.04 \times 10^{-5}\end{array}$ & Yes & 37 & 33 & 1.50 \\
\hline 2 & 9.156 & 11.565 & -26.32 & $t(70)=1.07, p=0.288$ & No & 37 & 33 & 1.50 \\
\hline 3 & 2.239 & 2.545 & -13.67 & $\begin{array}{c}t(80)=0.457 \\
p=0.649\end{array}$ & No & 37 & 33 & 1.50 \\
\hline 4 & 1.010 & 0.372 & 63.19 & $\begin{array}{l}t(50)=3.65 \\
\quad p=6.18 \times 10^{-4}\end{array}$ & Yes & 37 & 33 & 1.50 \\
\hline 5 & 4.060 & 2.192 & 46.00 & $t(61)=2.07, p=0.042$ & Yes & 37 & 33 & 1.50 \\
\hline 6 & 3.964 & 1.651 & 58.35 & $t(55)=2.55, p=0.014$ & Yes & 37 & 33 & 1.50 \\
\hline
\end{tabular}

test. Each test consisted of five baseline traverses and five foam traverses.

Foam property tests were conducted during the foam traverses, measuring foam expansion ratio and foam water drainage. Foam was collected in a vessel with a specific volume in order to calculate the expansion ratio and measure the water drainage. Foam expansion was calculated as:

$E=V_{\mathrm{e}} /\left(W_{\mathrm{f}}-W_{\mathrm{e}}\right)$ where, $E$ is the nondimensional expansion of the foam; $V_{\mathrm{e}}$ is the known volume of the empty collection vessel, in milliliters; $W_{\mathrm{f}}$ is the weight of the full collection vessel, filled with foam, in grams; and $W_{\mathrm{e}}$ is the weight of the empty collection vessel, in grams.

Drainage was determined by measuring the amount of water that drained off the foam that was collected in the vessel (Reed et al. 2018). These properties are used to characterize foams. 


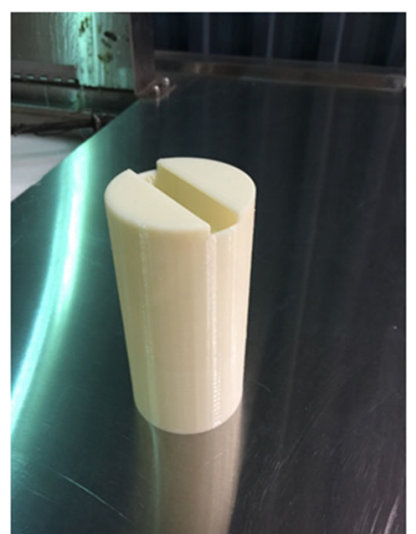

Fig. 5 The NIOSH 3D printed nozzle \#2 blower foam nozzle (50.8$\mathrm{mm}$ (2-in) diameter)

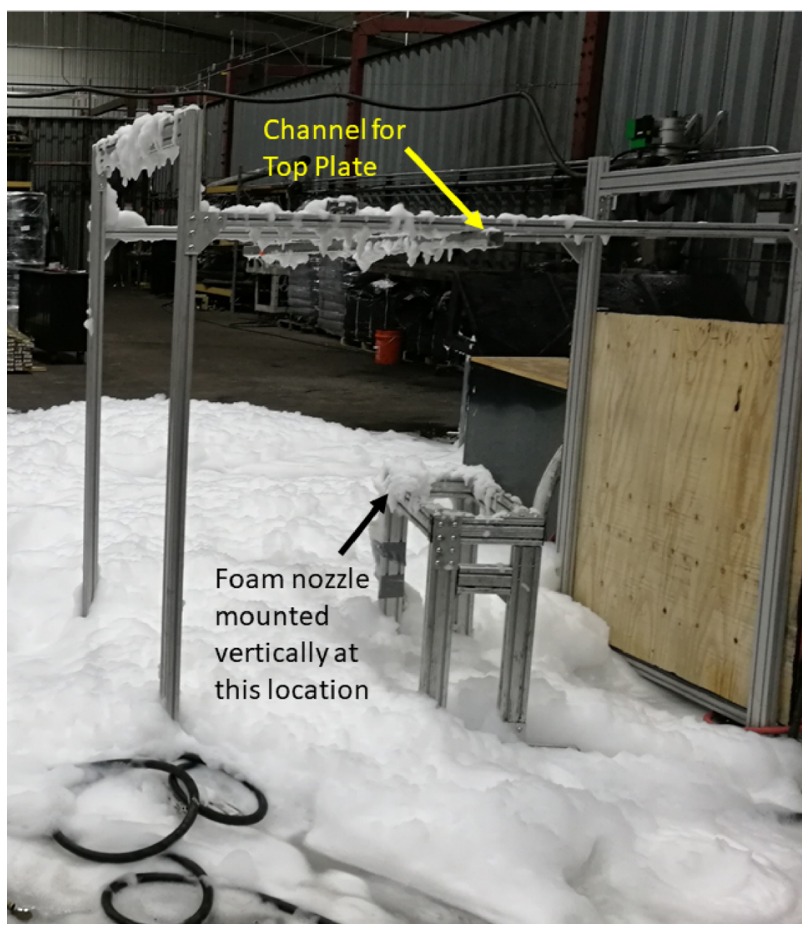

Fig. 6 The structure used to apply foam to the top plate; top plate not shown

Previous foam roof application testing showed that foam roof application was highly dependent upon nozzle type. A nozzle was required in order to achieve adequate foam coverage over the top plate. The NIOSH-designed 3D nozzle \#2, which is basically a hollow tube with a slot at the end where foam discharge occurs, is shown in Fig. 5. It was used as it provided better coverage over the roof than other nozzles that were previously tested for roof application (Reed et al. 2017).

To enable the application of foam to the top plate, a separate structure was built (Fig. 6) nearby the test facility which allowed the top plate to be held horizontal and slide

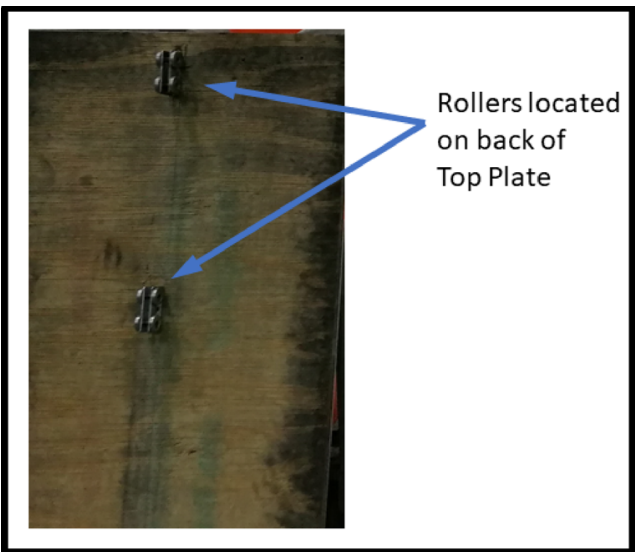

Fig. 7 The back of the top plate depicting the rollers which allow the top plate to pass over the foam nozzle

forward through the use of rollers attached to the back of the top plate (Fig. 7). The rollers of the plate passed through a channel built onto the structure. The foam nozzle was mounted vertically and located 36 inches below the top plate. When foam application was required, foam was sprayed from the nozzle until it stabilized, i.e., the foam discharged at a consistent rate with no sputtering. Then, the top plate was passed forward through the foam spray coating the top plate. After the one pass, the top plate was then immediately inserted into the longwall test facility.

The following are the procedures for the dust-only tests or baseline tests and the foam tests:

The wind tunnel fan was started, and air velocity was measured and recorded at the beginning and end of the test using a vane anemometer. The air velocity at the beginning of the test was adjusted to either $3.0 \mathrm{~m} / \mathrm{s} \pm 0.3 \mathrm{~m} / \mathrm{s}(600$ $\mathrm{fpm} \pm 50 \mathrm{fpm}$ ) (low velocity) or $5.1 \mathrm{~m} / \mathrm{s} \pm 0.3 \mathrm{~m} / \mathrm{s}(1000$ $\mathrm{fpm} \pm 50 \mathrm{fpm}$ ) (high velocity), depending upon the test being conducted. No method of recording air velocity during the test was available. Psychrometric data was measured and recorded. The pDR samplers were then initiated for the test. The bottom plate was loaded using the $12.7-\mathrm{mm}(1 / 2-\mathrm{in}) \mathrm{jig}$, pre-weighed, and installed in the test facility. All doors/openings were closed, and the test was initiated. The computer recorded start and stop times of the test and controlled the movement of the bottom test plate across the facility. The bottom test plate with the sample material followed the pre-programmed cycle-lower, advance, and then load-which simulated shield movement. Once the test plate returned to the home position, the facility and both plates were cleaned, and testing was repeated for 5 trials.

The foam dust control tests followed a similar procedure with a few modifications. The first was prior to loading the bottom plate with test material, the top plate was removed, wetted with water, and then thoroughly covered with foam 
and then re-installed. During testing, the foam expansion ratio and foam drainage analyses (Foam drainage tests are a 10-min test, which is why they were not conducted on each trial) were conducted at the beginning, middle, and end, which refer to the foam property and drain down tests that will be completed at trial 1 (beginning), trial 2 or 3 (middle), and trial 5 (end). The second was when initiating bottom plate movement, the bottom test plate was allowed to lift until the material compressed on the top plate, and a 3-min wait time was implemented before allowing the bottom plate to finish its cycle. As mentioned previously, the 3-min wait time simulated the time between foam spraying or application to the roof and movement of the longwall shield. The 3-min wait time was not needed for the dry roof tests. The facility and both plates were thoroughly cleaned, and the testing was repeated for 5 trials.

\section{Results}

Tables 3, 4, 5, 6, 7 and 8 show the percent changes in dust using foam by comparing the average measured dust concentration values of the average of the five traverses. The dust concentration values analyzed were the uncorrected data recorded by $\mathrm{pDRs}$ (recording at $0.5 \mathrm{~s}$ intervals) for each traverse. The data that was analyzed for each traverse was the data from the time the plate hits the roof $(7.0 \mathrm{~s})$ to the return and lowering of the plate $(27.5 \mathrm{~s})$, resulting in about 42 data points per traverse at each sampling location. All five traverses for the baseline were averaged, averaging each of the five 1 data points, each of the five 2 nd data points sequentially to each of the five 42 nd data points. This calculation was also completed for the foam data, but once the plate hit the roof at $7.0 \mathrm{~s}$ there was a 3-min wait until the traverse started. No sampling occurred during this 3-min wait. Therefore, the traverse for foam was from 180.0 to $207.5 \mathrm{~s}$ (42 data points). This resulted in one single traverse containing 42 data points for baseline and for foam, which was used in the comparison for the baseline and the foam data.

The "Location" column in Tables 3, 4, 5, 6, 7 and 8 represents the location of the sampler in the test facility. The locations 1, 2, and 3 are the samplers equally spaced and located in the first row, the row nearest the shield movement simulator. The locations 4, 5, and 6 are the samples located in the second row. The sampler location numbers increased from the double-door side of the facility across toward the backside, i.e., 1 was near the double-door side, 2 in the middle, and 3 next to the backside wall (Fig. 1). Locations 4, 5, and 6 were located similarly.

Since the concentrations are relative concentrations, comparisons can be made of results from the same location. For example, location 2 of one test can be compared with location 2 of another test. However, location 2 cannot be compared with other locations (locations 1, 3, 4, 5, and 6).

The "Baseline" column shows the average respirable dust concentration in $\mathrm{mg} / \mathrm{m}^{3}$ for the average of the five traverses completed without any dust control agent. The "Foam" column shows the average respirable dust concentration in $\mathrm{mg} / \mathrm{m}^{3}$ for the average of the 5 traverses when the roof section was coated with foam. The "\% Change" column shows the percent reduction $(+)$ or percent increase (-) of the baseline and foam comparison. The " $t$ test@95\% confidence" column shows the results of the $t$ test, using $95 \%$ confidence, comparing the average of the five individual traverse data for the baseline and foam conditions.

\section{Discussion}

In reviewing the use of foam to control dust generated from the gravel mixture by longwall shields, foam appeared to be successful at both low- and high-ventilation velocities. Foam agents $\mathrm{A}$ and $\mathrm{C}$ had significant percent changes at both velocities, albeit foam A reductions were lower during high-velocity ventilation. Foam agent B worked well at low velocities but did not perform as well for high velocities.

The overall reductions using foam agent $\mathrm{A}$ at low velocity (about $3.0 \mathrm{~m} / \mathrm{s}(600 \mathrm{fpm})$ ) ranged from $33 \%$ to $83 \%$ with an average foam expansion ratio of 44.1 and an average water drainage of $4 \mathrm{ml}$. At the second row with locations 4,5 , and 6 , the reductions were very good ranging from $71 \%$ to $83 \%$. All reductions were statistically significant at $95 \%$ confidence level, except for location 3 . In high-velocity ventilation (about $5.1 \mathrm{~m} / \mathrm{s}$ (1000 fpm)), the overall dust reductions were lower, ranging from $28 \%$ to $48 \%$ with an average foam expansion ratio of 47.5 and an average water drainage of $0 \mathrm{ml}$. All locations were statistically significant at the $95 \%$ confidence level, except for location 3. There were two instances when an increase in dust concentrations occurred when using the foam agent A. They were at location $1(-1590 \%)$ and location 4 $(-236 \%)$. The cause of the increases in dust $\left(0.377-6.373 \mathrm{mg} / \mathrm{m}^{3}\right)$ for location 1 and $(0.827-2.776 \mathrm{mg} /$ $\mathrm{m}^{3}$ ) for location 4 during the use of foam as a control agent is not known. However, both increases occurred at the beginning of the traverse. Possible explanations could be lack of foam coverage in the area for the locations 1 and 4 samplers, the material on the lower plate allowed a large amount of fine particle-sized material to drop during initial movement, or the foam did not penetrate the mixed material on the lower plate at initial movement. However, the dust reductions from $28 \%$ to $48 \%$ are supportable. These reductions are lower than the reductions at the lower 
velocity reductions. During previous roof application testing, foam coverage at high-velocity ventilation was not as good as that provided at low-velocity ventilation (Reed et al. 2017). The reduction in coverage at high-velocity ventilation would explain the high-velocity ventilation's lower dust reductions.

The reductions using foam agent $\mathrm{B}$ at low velocity (about $3.0 \mathrm{~m} / \mathrm{s}(600 \mathrm{fpm})$ ) ranged from $48 \%$ to $66 \%$ for locations 4,5 , and 6 with an average foam expansion ratio of 54 and a water drainage of $26 \mathrm{ml}$. There was one instance of an increase in dust concentrations during the use of foam as a control agent. It occurred at location 1 with a $-41 \%$ reduction or an increase in dust. However, the dust concentrations at location 1 were very low, ranging from 0.118 to $0.167 \mathrm{mg} / \mathrm{m}^{3}$. All reductions were statistically significant at $95 \%$ confidence level, except for locations 2 and 3. In high velocity ventilation (about $5.1 \mathrm{~m} /$ $\mathrm{s}(1000 \mathrm{fpm}))$, there were no dust reductions, only increases in dust concentrations: $-79 \%$ and $-307 \%$ at locations 2 and 3, respectively, with the foam expansion ratio of 56 and a water drainage of $20 \mathrm{ml}$. Only these two locations were statistically significant at the $95 \%$ confidence level. Possible explanations are most likely lack of foam coverage on the top surface plate. During previous roof application testing, foam coverage with agent $\mathrm{B}$ at high-velocity ventilation was not good (Reed et al. 2017). Therefore, the reduction in coverage at high-velocity ventilation would explain the lack of dust control in highvelocity ventilation resulting in increases at several of the locations.

The overall reductions using foam agent $\mathrm{C}$ at low velocity (about $3.0 \mathrm{~m} / \mathrm{s}(600 \mathrm{fpm})$ ) ranged from $47 \%$ to $63 \%$ with an average foam expansion ratio of 49 and an average water drainage of $36 \mathrm{ml}$. There was one increase in dust concentrations at location $1(-341 \%$ or $0.549-2.424 \mathrm{mg} / \mathrm{m}^{3}$ ). This increase is significantly large. Possible explanations are similar to those provided when discussing the increases that occurred during the use of foam agent $\mathrm{A}$ in high-velocity ventilation. All locations were statistically significant at $95 \%$ confidence, except for locations 2 and 3. All reductions occurred at the second row. In high velocity ventilation (about $5.1 \mathrm{~m} / \mathrm{s}(1000$ fpm)), the overall dust reductions ranged from $46 \%$ to $89 \%$ with an average foam expansion ratio of 37 and an average water drainage of 33. All locations were statistically significant at the $95 \%$ confidence level except for location 2 and 3 . At the second row with locations 4,5 , and 6 , the reductions were very good ranging from $46 \%$ to $63 \%$.

The results show that all foam agents can provide dust concentration reductions in the longwall shield dust facility, especially when reviewing the second row of sampling locations (locations 4, 5, and 6). Comparisons at specific locations do show performance variations at low-velocity ventilation. The purpose of the testing was to show the use of foam agents is feasible for longwall shield dust control. In addition, because the concentrations from pDRs are relative concentrations, the variations among the different locations cannot be compared.

The evaluation of the second-row result is most likely a better evaluation, as it is sufficient distance from the source that contamination from a large amount particles and foam contamination is not an issue with the sampling instruments. When reviewing the dust measurements from the second row of samplers, foam agents A and B provide at least $45 \%$ dust reductions up to $66 \%$. One foam agent $C$ had reductions from $71 \%$ to $83 \%$. At high-velocity ventilation, the reduction of longwall shield dust using foam is different. The changes are more variable ranging from $46 \%$ to $63 \%$ for foam agents A and C. Foam agent B's percent changes were statistically insignificant if the second row is used for calculating the average reduction for the high velocity ventilation tests. It should be noted that foam agent A had one instance of a dust increase of $236 \%$. This variability is most likely caused by the variation of foam coverage on the roof as the high-ventilation velocity tends to shear the foam from the roof. However, the manufacturers of the foam agents may be able to add additional chemical agents, which would improve the ability of foam to remain in place at high velocities, therefore, resulting in improving the performance of foam for longwall shield dust reductions at high-ventilation velocities.

\section{Conclusions}

The use of foam is a promising dust control for longwall shield dust. At low-ventilation velocities of approximately $3.0 \mathrm{~m} / \mathrm{s}(600 \mathrm{fpm})$, all foam agents were able to provide at least $45 \%-66 \%$ reductions of dust concentrations (foam agents $\mathrm{A}$ and $\mathrm{B}$ ). One foam agent was able to provide up to $71 \%-83 \%$ dust reduction (foam agent $\mathrm{C}$ ). The results from this lab testing are anticipated to be a predictor of results for the use of foam as a longwall shield dust control method. But corroboration of these lab results will require results from field testing to authenticate this assertion.

At high-ventilation velocities of approximately $5.1 \mathrm{~m} / \mathrm{s}$ (1000 fpm), the reductions in dust concentrations were lower and much more variable, with reductions ranging from $46 \%$ to $63 \%$ (foam agents A and C), with one instance of an increase in dust concentration. Foam agent B's reductions were statistically insignificant, meaning that the use of foam may not be the only reason for the reduction. The reason for the lower reductions and variability in reductions is due to the lack of coverage and inability of foam to remain on the top surface plate during high-ventilation velocities. High-ventilation velocities tended to 
shear the foam from the roof creating gaps in roof coverage.

Foam data (expansion ratio and water drainage) were collected for each foam agent. When evaluating these properties for each foam agent, the properties were consistent for each agent, based upon previous foam property testing. Based upon observations of foam testing, it seemed that foams with higher expansion ratios had reduced roof coverage. This is because the higher expansion ratio foams were lighter and were more easily removed from the roof by the airflow ventilation velocities.

Future testing in the mine will be required to definitively characterize the ability of foam for use as a longwall shield dust control. Additional work will be required to develop mine-worthy foam-generating equipment to allow proper application of foam to the mine roof.

Author contributions The author contributions include: WRR; direct project tasks and lab experiments, conduct data analysis, and writing of document. MRS assist with project tasks and lab experiments, conduct data analysis, and writing of document. YZ; assist with project tasks and lab experiments, conduct data analysis, and writing of document. AM; assist with lab experiments and review of analysis and document. JD; assist with lab experiments and review of analysis and document.

Funding There is no funding information, all work was conducted by the authors as part of their job duties.

Data availability The data can be made available from the authors upon request.

\section{Compliance with ethical standards}

Conflict of interest There are no conflict of interest among any of the authors.Human participants and or animal rights.This research does not involve any animals, humans, human data, human tissue, or plants. No personal data was used.

Human participants and or animal rights This research does not involve any animals, humans, human data, human tissue, or plants. No personal data was used.

Open Access This article is licensed under a Creative Commons Attribution 4.0 International License, which permits use, sharing, adaptation, distribution and reproduction in any medium or format, as long as you give appropriate credit to the original author(s) and the source, provide a link to the Creative Commons licence, and indicate if changes were made. The images or other third party material in this article are included in the article's Creative Commons licence, unless indicated otherwise in a credit line to the material. If material is not included in the article's Creative Commons licence and your intended use is not permitted by statutory regulation or exceeds the permitted use, you will need to obtain permission directly from the copyright holder. To view a copy of this licence, visit http://creativecommons. org/licenses/by/4.0/.

\section{References}

Belle BK, Du Plessis JJL, Oberholzer J (2000) A field evaluation of the BGI and cowl type gravimetric samplers. J Mine Vent Soc South Afr 10-15

Chekan GJ, Listak JM, Colinet JF (2004) Factors impacting respirable dust entrainment and dilution in high-velocity airstreams. PrePrint \#: 04-10. SME annual meeting, Feb 23-25, 2004, Denver, $\mathrm{CO}$

Code of Federal Regulations, CFR 75.344 (2018) Code of Federal Regulations, 75.344 Compressors. CFR Title 30, Chapter I, Subchapter O, Part 75, Subpart B, 75.344, U.S. Government Printing Office, National Archives and Records Administration, Washington, D.C.

Fiscor S (2020) US Longwall census-longwalls lead the way underground. Coal Age 125(1):16-24

Görner P, Simon X, Wrobel R, Kauffer E, Witschger O (2010) Laboratory study of selected personal inhalable aerosol samplers. Ann Occup Hygiene 54(2):165-187. https://doi.org/10. 1093/annhyg/mep079

Komatsu Joy Global (2020) https://mining.komatsu/product-details/ powered-roof-supports. Accessed 24 Mar 2020

Reed WR, Potts JD, Cecala AB, Archer WJ (2012) Use of the 1500 -pDR for gravimetric respirable dust measurements at mines. Trans Soc Min Metall Explor 332:514-520

Reed WR, Zheng Y, Klima S, Shahan MR, Beck TW (2017) Experimental study on foam coverage on simulated longwall roof. Trans Soc Min Metall Explor 342:72-82.doi:https://doi. org/10.19150/trans.8110.

Reed WR, Beck TW, Zheng Y, Klima S, Driscoll J (2018) Foam property tests to evaluate the potential for longwall shield dust control. Min Eng 70(1):35-41

Shahan MR, Reed WR (2019) The design of a laboratory apparatus to simulate the dust generated by longwall shield advances. Int $\mathbf{J}$ Coal Sci Technol 6(4):577-585. https://doi.org/10.1007/s40789019-00273-4

Williams K, Timko R (1984) Performance evaluation of a real-time aerosol monitor. information circular 8968. U.S. Dept. of the Interior, U.S. Bureau of Mines, Pittsburgh, PA 